\title{
Instalación de "sondas digestivas ectopicas" en pacientes con patología de cabeza y cuello y otras diversas, cuando las vías naturales no son practicables o no se consideran convenientes. Una nueva metodología
}

\author{
"Ectopic enteral tube" insertion in patients with head, neck and other pathologies \\ when natural tracts are impracticable or inadvisable. A new method
}

\author{
F. Hernández-Altemir' , S. Hernández-Montero², S. Hernández-Montero³ ${ }^{3}$ E. Hernández-Montero ${ }^{4}$, \\ M. Moros-Peña ${ }^{5}$
}

\begin{abstract}
Resumen: Introducción. Es frecuente que en los pacientes con patología general diversa y del territorio oral y maxilofacial tengamos que dotarles de medios extraordinarios para facilitar la alimentación y aspiración digestiva. Presentamos una nueva metodología para la instalación de lo que denominamos Sondas Digestivas Ectópicas (SDE). Material y Método. Empleamos las sondas digestivas convencionales, sólo que haciéndolas llegar al tramo digestivo por lo que denominamos vías ectópicas de instalación y entre las más habituales en nuestras manos estaría, la sonda digestiva pericraneal o submental o a través de heridas y trayectos creados o no del territorio craneofacial. Presentamos un caso clínico de un paciente con fracturas conminutadas del territorio craneomaxilofacial al que la SDE se instaló en la región temporal y supracigomática izquierda. Resultados. Conseguimos con esta nueva metodología evitar técnicas más agresivas como la gastrostomía percutánea o quirúrgica y evitar el uso de los la via nasal u oral, cuando éstos no son practicables o no están indicados manteniendo una vía fiable de aspiración y alimentación digestiva. Conclusiones. Los beneficios de esta técnica deben hacer que incorporemos la SDE en nuestro arsenal terapéutico.
\end{abstract}

Palabras clave: Sonda digestiva ectópica; Vías pericraneal; Vía submental.

Recibido: 31.01 .07

Aceptado: 31.10 .07

1 Jefe del Servicio de Cirugía Oral y Maxilofacial.

Hospital Universitario Miguel Servet de Zaragoza y Hospital MAZ, Zaragoza, España

2 Práctica Privada Cirugía Oral y Maxilofacial y Profesora y Coordinadora.

Universidad Alfonso X el Sabio (Facultad de Odontología), Madrid, España

3 Práctica Privada (Endodoncia), Zaragoza, España

4 Hospital de Viladecans e Instituto de Otoneurocirugía García-lbáñez, Barcelona, España

5 Práctica privada Pediatría y Puericultura (Dibujante), Zaragoza, España

\section{Correspondencia:}

Dr. Francisco Hernández Altemir

Hospital Universitario Miguel Servet

po Isabel la Católica 1-3

50009 Zaragoza, España

Email: drhernandezaltemir@yahoo.es

\begin{abstract}
Introduction. Patients with a variety of general pathologies and oral and maxillofacial pathologies often require extraordinary measures for to ensure enteral feeding and aspiration. We report a new method for inserting what we call "ectopic enteral tubes" (EET). Material and Method. Conventional enteral tubes are inserted into the digestive tract using "ectopic" insertion routes. At present, the most common routes available are the pericranial or submental routes, as well as wounds and trajectories that are present or created expressly for this purpose in the craniofacial area. We report the clinical case of a patient with comminuted fractures of the temporal and left suprazygomatic region, where the EET was inserted. Results. This new method obviates the need for more aggressive techniques, such as surgical or percutaneous gastrostomy, and the use of natural facial orifices when not practicable or not indicated while maintaining a viable route for enteral feeding and aspiration. Conclusions. EET is a useful addition to our therapeutic arsenal.
\end{abstract}

Key words: Ectopic enteral tubes; Pericranial route; Submental route. 


\section{Introducción}

Es práctica frecuente en los pacientes con patología general diversa y del territorio oral y maxilofacial y de especialidades afines de cabeza y cuello, el tener que dotarles de medios extraordinarios para facilitar la alimentación y aspiración digestiva en momentos postoperatorios o no, y no siempre es posible emplear la vía nasal o la oral, teniendo que recurrir a técnicas más invasivas, cómo pueden ser la gastrostomía percutánea ${ }^{1}$ (GP) o quirúrgica (GQ) que para situaciones temporales, deben evitarse. Por ello proponemos lo que denominamos instalación de sondas digestivas ectópicas (SDE), que no dejan de ser, sondas convencionales, que se disponen a distancia de los orificios aerodigestivos de la cara.

\section{Material y método}

Empleamos las sondas digestivas convencionales, sólo que haciéndolas llegar al tramo digestivo por lo que denominamos vías ectópicas de instalación y entre las más habituales en nuestras manos estaría, la sonda digestiva por vía pericraneal o submental (que rememora nuestra técnica de intubación endotraqueal por vía submental)2,3 o a través de heridas y trayectos creados o no del territorio craneofacial, que se puedan considerar idóneas para salvar situaciones excepcionales, cuando como decíamos los orificios naturales son impracticables o no convenientes, por las características de la patología, y o por la idiosincrasia del paciente, que a veces no toleran las sondas digestivas nasales $\mathrm{u}$ orales, arrancándoselas no pocas veces. Las vías ectópicas pueden ser menos invasivas, al evitar los espacios naturales nasales $u$ orales, sin duda muy sensibles a la presencia y paso de "cuerpos extraños" (Figs. 1-5).

Presentamos un caso clínico de un paciente con fracturas conminutadas del territorio craneomaxilofacial (Figs. 6 y 7) y al que la SDE se instaló pericranealmente en la región temporal y supracigomática izquierda, buscando el espacio oral, vestibular retromaxilar y laterofaríngeo para terminar en el fundus gástrico, con comprobación peroperatoria, mediante la insuflación de aire y control estetoscópico por el anestesiólogo, fijando la porción proximal de la SDE con un punto de seda alrededor de la herida pericráne-

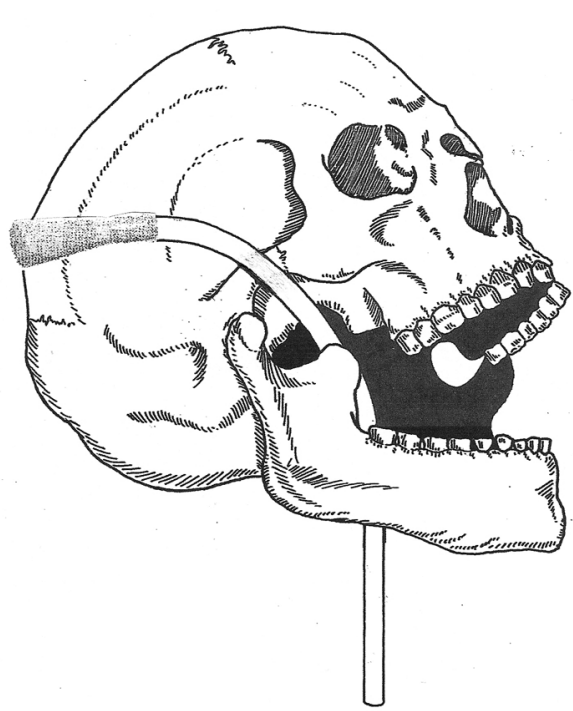

Figura 1. Visión lateral de la Sonda Digestiva Ectópica Supracigomática.

Figure 1. Lateral view of suprazygomatic ectopic gastric tube.

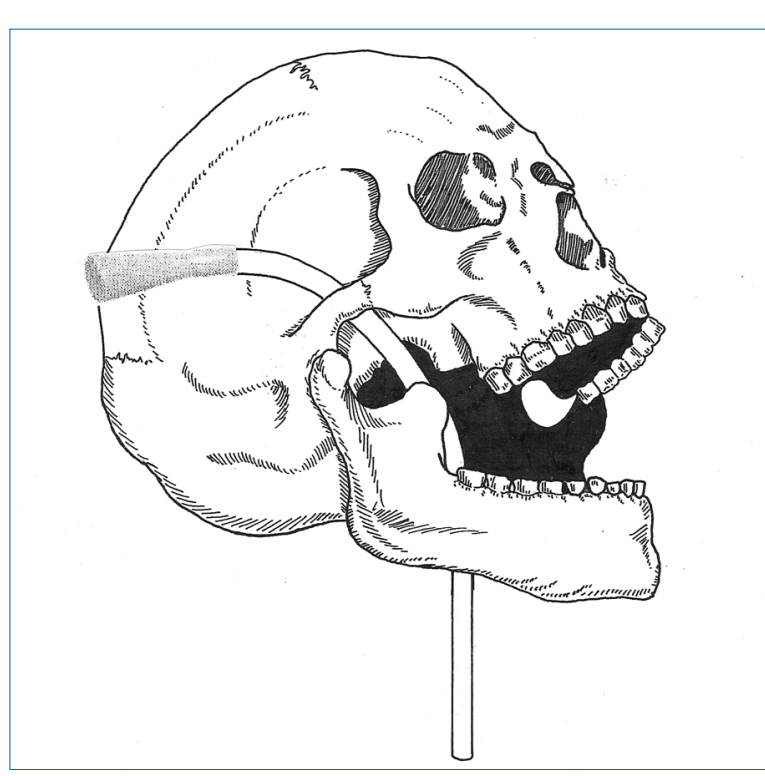

Figura 2. Visión lateral de la Sonda Digestiva Ectópica Infracigomática.

Figure 2. Lateral view of infrazygomatic ectopic gastric tube.

\section{Introduction}

Extraordinary measures often are needed in patients with a variety of general pathologies and specific oral, maxillofacial and head and neck pathologies to ensure enteral feeding and aspiration postoperatively and at other times. The nasal or oral tracts cannot always be intubated and more invasive techniques may be used temporarily, such as percutaneous gastrostomy' (PG) or surgical gastrostomy (SC), which should be avoided. We propose the use of what we call "ectopic enteral tubes" (EET), which are conventional tubes inserted at some point other than the respiratory and digestive orifices of the face.

\section{Material and Method}

We insert conventional enteral tubes into the digestive tract by what we call "ectopic" routes. Among the routes most often used are the pericranial and submental routes (the latter similar to our submental endotracheal intubation technique).2,3 Wounds and passages in the craniofacial area that are present or opened expressly for the purpose are also used. These routes are suitable for exceptional situations, such as when the natural orifices are impracticable or unsuitable due to the nature of the pathology and/or patient idiosyncrasies. Patients occasionally cannot tolerate a nasally or orally inserted gastric tube and sometimes go so far as to pull the tube out. Ectopic routes can be less invasive, by avoiding the natural nasal or oral spaces, which undoubtedly are very sensitive to the presence and passage of "foreign bodies" (Figs. 1 to 5).

We report the clinical case of a patient with comminuted fractures of the craniomaxillofacial area (Figs. 6 and 7). The EET was inserted pericranially in the temporal and left suprazygomatic region by seeking out the oral space 


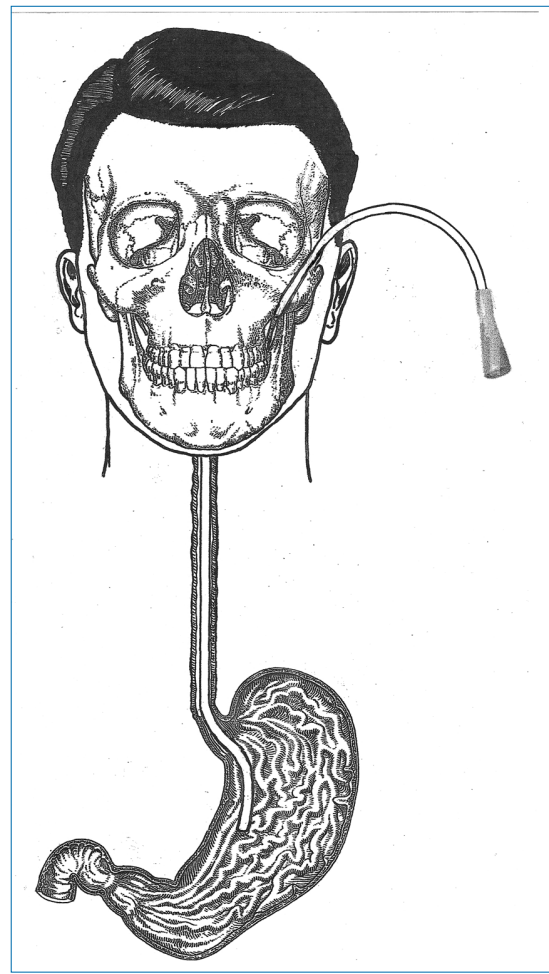

Figura 3. Visión frontal de la Sonda Digestiva Ectópica Supracigomática.

Figure 3. Frontal view of suprazygomatic ectopic gastric tube.

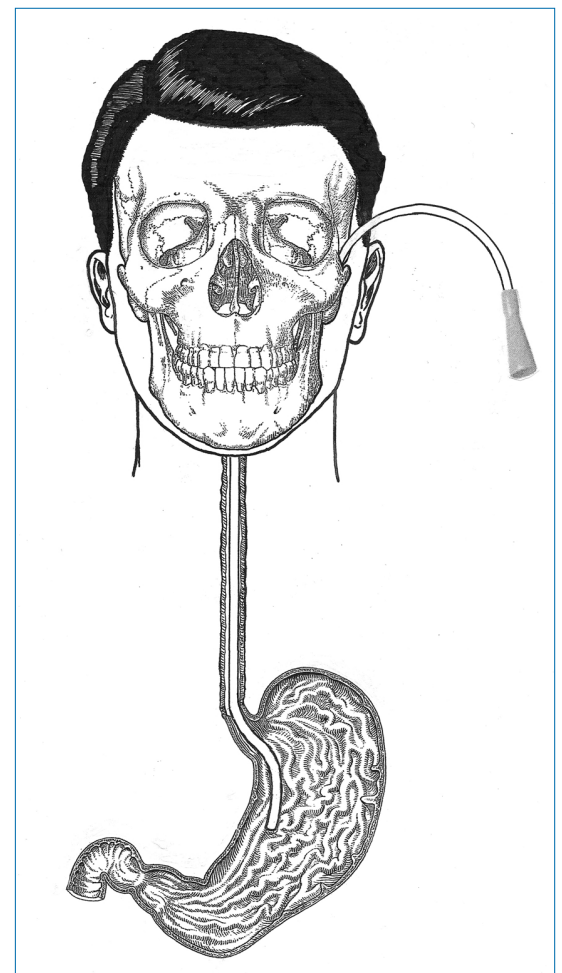

Figura 4. Visión frontal de la Sonda Digestiva Ectópica Infracigomática.

Figure 4. Frontal view of infrazygomatic ectopic gastric tube.

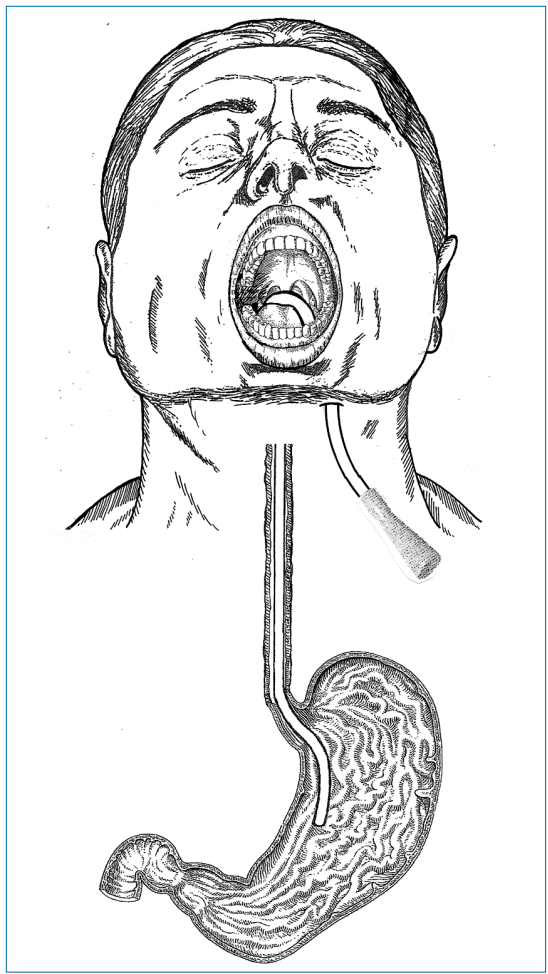

Figura 5. Colocación de la Sonda Digestiva Ectópica por Vía Submental.

Figure 5. Submental positioning of ectopic gastric tube.

al, en éste caso, rodeándola dos o tres veces. En nuestro primer paciente por esta vía, la sonda estuvo instalada y funcionante quince dias y se le retiró al recuperar el mismo su capacidad deglutoria. (Fig. 8).

La sonda deberá instalarse si es pericraneal por detrás de la línea del cabello o heridas de la zona, si se estiman adecuadas. En el caso de la sonda por vía submental se procurará un trayecto oblícuo,

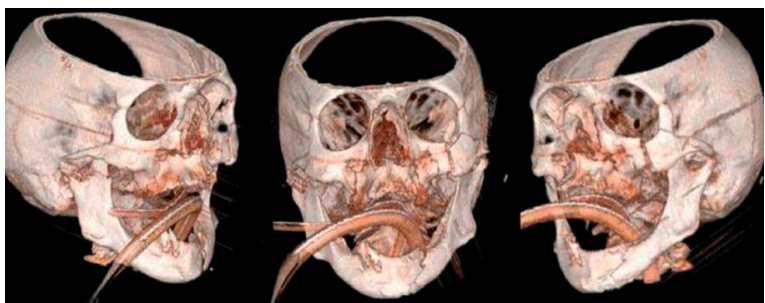

Figura 6. TC 3-D Preoperatorio mostrando las fracturas panfaciales conminutadas.

Figure 6. Preoperative 3-D CT scan showing panfacial comminuted fractures. hacia atrás desde la piel para dificultar la formación de posibles fístulas cuando se retire la sonda.

Para retirar la SDE pericraneal, se tendrá en cuenta el hacerlo lo más asépticamente, evitando que la porción digestiva de la misma discurra por su lugar de inserción, para lo cual siempre que se pueda se seccionará y extraerá previo control, intraoralmente. Si el enfermo lleva bloqueo intermaxilar, la SDE deberá salir por su lugar de inserción si la sonda se hubiera instalado por vía submental.

En caso de tener que mantener las sondas digestivas prolongadamente, en pacientes habitualmente intervenidos de patología oral y maxilofacial y pasada la fase crítica, se sustituirán, si es posible, por una sonda convencional por via nasotraqueal. Si la sonda digestiva va a ser permanente se valorara una SDE o una gastrostomía.

through the retromaxillary vestibule and lateropharyngeal space, and terminating in the gastric fundus. The position was verified peroperatively by insufflating with air under stethoscopic control by the anesthesiologist. The proximal end of the EET was secured with silk suture around the pericranial wound, in this patient by wrapping the suture around the tube two or three times. In the first patient in which we used this route, the ectopic enteral tube functioned for fifteen days and then was removed when the patient recovered swallowing function (Fig. 8).

The pericranial tube is inserted behind the hairline or through local wounds, if suitable. In the case of submental intubation, an oblique route going from the skin and backward is used to prevent fistula formation after the tube is removed.

Pericranial EETs should be removed as aseptically as possible, without extracting the digestive end of the tube through the route of insertion. Whenever possible, the tube should be sectioned and extracted orally under imaging control. In patients with intermaxillary fixation, submentally inserted 


\section{Discusión}

El procedimiento de instalación de las sondas digestivas ectópicas sin duda, se debe dejar en manos del especialista de cabeza y cuello, quién sabrá también ayudar a las indicaciones y llevar a efecto el procedimiento quirúrgico más adecuado, para cada caso.

En definitiva, tratamos que los especialistas de Endocrinología y Nutrición, las Unidades de Cuidados Intensivos, Servicios de Anestesiología y Reanimación, etc., tanto en el adulto, como en el neonato y recién nacido, y en particular, los Especialistas de Cabeza y Cuello, como Cirujanos Orales y Maxilofaciales y Otorrinolaringólogos, también en Cirugía Plástica y Quemados, Oncólogos generales o no, puedan acudir a nuestro procedimiento evitando a veces las vías convencionales o técnicas más invasivas, ${ }^{4}$ como las GP o $\mathrm{GQ}$, con apoyo o no de nutrición parenteral, si sólo se tratara de alimentar al paciente.

\section{Conclusiones}

Las vías extraordinarias pueden suplir a las ordinarias y clásicas y tal vez convertirse según se tenga experiencia en procedimientos muy habituales para casos seleccionados.

La instalación de la Sonda Digestiva Ectópica debe engrosar nuestro arsenal terapéutico.

\section{Bibliografía}

1. Gauderer MW. Percutaneous endoscopic gastrostomy and the evolution of contemporary long-term enteral access. Clin Nutr 2002;21: 103-10.

2. Hernández Altemir F. Intubación endotraqueal por vía submental. Una nueva técnica. Rev Ibero americana de Cirugía Oral y Maxilofacial 1984;6.

3. Hernández Altemir $F$. The submental route for endotracheal intubation. A new technique. J Maxillofac Surg 1986;14:64-5.

4. Pavan Patil M, Neelkant Warad M, Rajshekar Patil N, Kotrashetti SM,. Belgaum, India KLE Institute of Dental Sciences, Rajiv Gandhi University of Health Sciences: Cervical pharyngostomy: an alternative approach to enteral feeding. Oral Surg, Oral Med, Oral Pathol, Oral Radiol, and Endod 102:736-40.
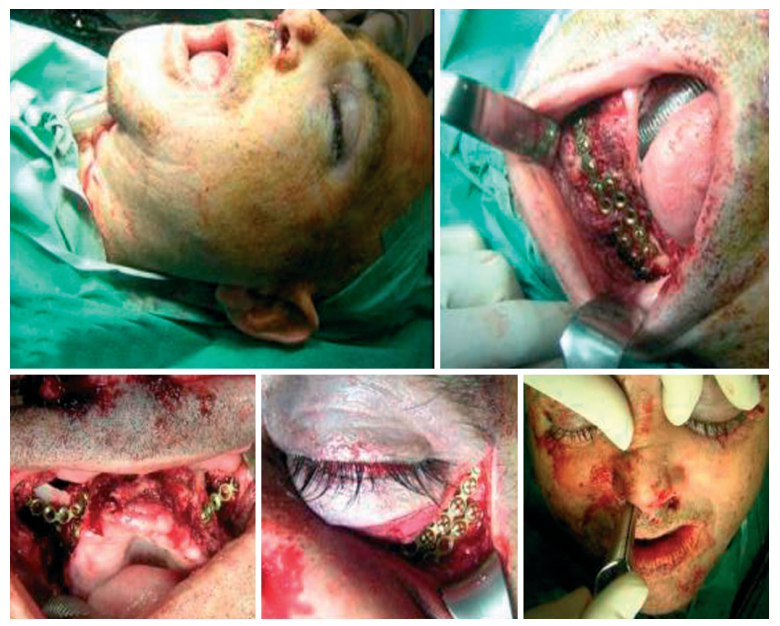

Figura 7. Secuencia quirúrgica: Intubación submental realizada, reducción mandibular, maxilar, orbitaria y nasal de las fracturas.

Figure 7. Surgical sequence: Submental intubation followed by mandibular, maxillary, orbital, and nasal fracture reduction.
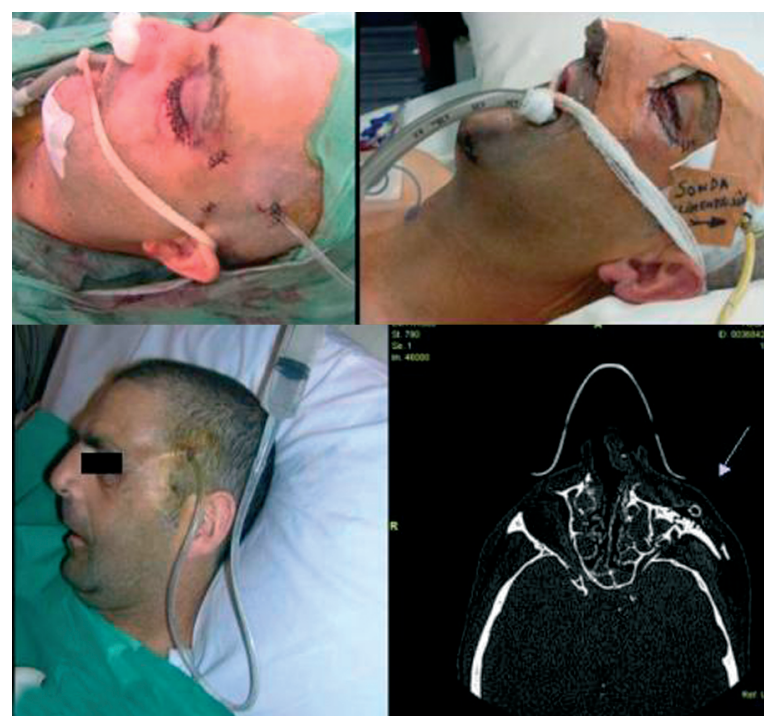

Figura 8. Postoperatorio con SDE (Sonda Digestiva Ectópica) supracigomática en quirófano, $\mathrm{UCl}$, habitación y detalle del TC postoperatorio donde se visualiza la luz de la Sonda de Alimentación.

Figure 8. Postoperative period with suprazygomatic EET (ectopic gastric tube) in operating room, UCl, and room. Detail of postoperative CT scan in which the lumen of the feeding tube is visualized.

\section{Discussion}

The ectopic enteral tube insertion procedure should be performed by a head and neck specialist who is familiar with the indications and can perform the most appropriate surgical procedure for each case. We propose our procedure for use by specialists in endocrinology and nutrition, intensive care units, anesthesiology and reanimation departments, etc., for adults as well as newborns. We particularly recommend it to head and neck specialists like oral and maxillofacial surgeons, ear, nose and throat specialists, plastic surgeons, burn specialists, and general and specialized oncologists. Our procedure avoids having to use more invasive conventional or technical routes, ${ }^{4}$ such as percutaneous or surgical gastrostomy, with parenteral nutrition or without it if the only aim is to feed the patient.

\section{Conclusions}

Non-conventional insertion routes can be used instead of conventional ones and may become routine procedures for selected cases as experience accrues.

Ectopic gastric tube insertion broadens the options available in the therapeutic arsenal. 